\title{
THE PLACE OF BIOLOGICAL SCIENCES IN THE MEDICAL CURRICULUM
}

\section{Introduction}

It is essential that the medical students should have a thorough basic training in biology with emphasis on human aspects. Medicine is one of the most important applied fields of biology. Biology gives information for tomorrow's doctors about their future patients, about human relationship to other living organisms.

In very branched medical curriculum medical students merely pick up isolated facts on human being - anatomy, physiology, histology etc. But biology gives a general scheme that shows students how all these facts are related and how all details in the human body work together to hold up status quo. Biology tries to answer the question "What is man?" and shows how any particular event in the ontogenesis of an individual (embryonic development, growth, illnesses) represents the human being as a whole system.

Biology gives an understanding of the unity of life on Earth. Doctors, like all of us, but may be more so, are responsible for our planet's future. Why? Because with all the deep similarities (e.g. genetic code, similar cell structure, chemical components) as well as endless differences, the humans, all other animals, plants, bacteria act together to produce our world. And man in this world is as much a part as the rest of all organisms.

The biological sciences in the medical curriculum at the faculty of Dentistry have always been taught. This paper gives in retrospect the 10 years experience (1990-2000) of teaching biological sciences at the Department of Medical Biology and Genetics at the Latvian Academy of Medicine / Riga Stradinš University.

Biology is taught to students of Dentistry in the $1^{\text {st }}$ and the $2^{\text {nd }}$ year. In the first year students obtain knowledge and skills in Human biology, in the second year they study Medical genetics with emphasis on oral - dental - craniofacial ( ODC) disorders.

\section{The description of the curriculum}

At present time two curricula of the biological sciences have been developed for the students of dentistry - Human Biology for the $1^{\text {st }}$ year students, and Medical 
Genetics for the $2^{\text {nd }}$ year students. The content studied in biology provides an opportunity to present science as the basis for medicine [1]. First year students should cover basic fields of biology because Medical Genetics cannot be adequately understood in isolation but only in the context of cell biology, formal genetics, developmental biology etc. Primary aims of the curriculum are as follows:

- To give students knowledge about general concepts of human biology.

- To form an understanding about dental genetic pathology and to stress the role of the dentist in early diagnosis, prevention and risk prognosis of genetic pathology.

- To develop skills of using this knowledge in medical practice and to help understand the role of science in practical fields of medicine.

The curriculum Human-Biology was designed to cover the core of biology. It includes such issues:

- The diversity of living organisms

- Human and environment

- Ontogenesis and evolution

- Biology of the cell

- Formal genetics.

The curriculum Medical Genetics in the medical curricula was introduced in 1995. The curriculum was developed considering the impact of a dental genetic pathology on public health and disease. It includes such issues:

- Primary dental genetic diseases

- Most common genetic diseases and their dental manifestation

- Branches of medical genetics

- Clinical application of medical genetics.

Because biology is one of the most rapidly advancing fields of science, the curriculum both of Human Biology and Medical Genetics are reevaluated and revised every year. The curriculum of biological sciences are clearly a work in progress.

In an attempt to advance quality education for dental students, the Department of Medical Biology and Genetics implemented several changes during the period of 1990-2000.

The changes in the curriculum were as follows:

1990 -self-creation of problem creating in genetics

1992 - case study in teaching ecology

1993 - small group activities were broadened by evaluating and discussing scientific papers 
1995 - elements of problem-based learning were used in the evaluation of environmental factors and health hazards in Latvia, participation in the genetic counseling of patients with DOC pathology at the Institute of Stomatology.

1996 - role-playing to foster genetic consultation

1997 - undergraduate project work was introduced as a part of the curriculum of Medical genetics, structured final examination as student assessment method

1999 - creating (by students) a web site in Latvian about the most common problems of genetic pathology in dentistry

2000 - discussion of scientific papers on current topic (student presentations during practical classes).

\section{Teaching - learning methods}

The studies should embrace practical and theoretical work. Nowadays teaching/learning have changed from teaching facts, to helping students to learn how to find relevant information, how to assess it [2]. The curriculum has two parts - lectures and practical classes. Lectures are given to all students of the faculty at the same time once a week. During lectures students receive basic knowledge in the subject. 2 lectures are changing part - every year innovations in the biology are given, such as Human Genome Project, Genetically modified food etc. Lecture material is demonstrated electronically. Lecture slides are available in the computers at the library and at computer classes.

During practical classes students are divided into small groups. In each small group 10-12 students are included. During practical classes students discuss lecture material, they obtain additional information about the topic and develop practical skills in microscopy, preparing and studying microscopic slides, analysis of schemes. Small group debates should be a part of biology classroom experience [3], and have been a part of biology curriculum for several years. Small group discussions are very fruitful. They promote students creative thinking, improve skills in communication, and develop students' analytical skills. Running the discussion in small groups is relatively simple in requires few materials. Students receive, for instance, some case report. Usually 2-4 case reports are and handed out students work in pairs or in smaller groups. Debate preparation lasts about 30 minutes and then students present their case, express their attitude and evaluation. Each year students supply several really good case reports. A sample case report is given below:

A couple has one healthy son. In their second pregnancy, prenatal diagnosis (amniocentesis) indicates that the fetus has XXY karyotype. The parents chose to abort the fetus.

Students have to calculate what is the risk to have an affected child; they should formulate their attitude and action plan as if they were consultants, or - parents. 


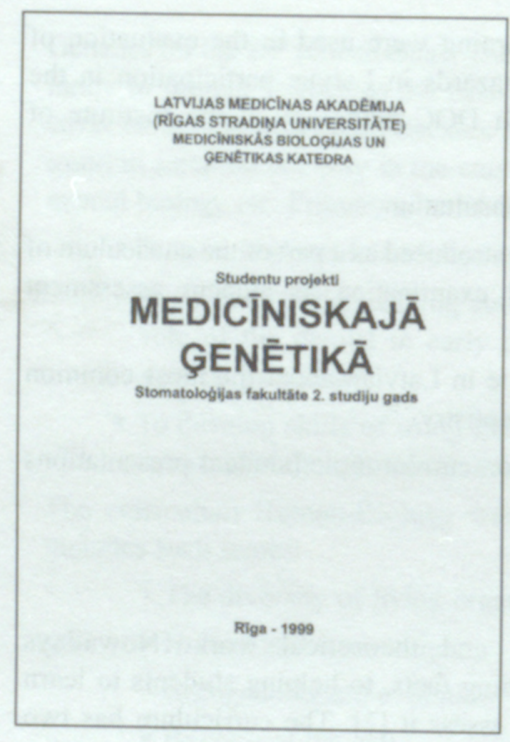

Lateljas Medichas atadtalla

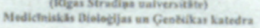

MEDIGINISKAJA ĢENETTIKẢ

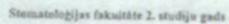

Brochures in medical genetics (in Latvian).

Student project works years 1998, 1999

eng - 19se

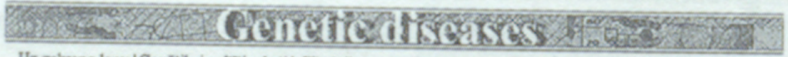


ketaloge

Esiet sveicinats mosu majjas lappusites viesil Priecljamies par apmeidejumu. Mẽs piedalvaljam informalciju par stomatoloßjsko genetisko patologiju. Mensu majjas lapa Jus vartesiet rast atbildes uz dă̌adiem ar genentisko patolokju saistetiem jautajumiem.

- Kapele mani, manu tuviniekou, draugu vai pacientu ir skalrusi fi slimiba?

- Kadas ir galvenlis simibu impausmes?



- Ka rolpeties par slimibas skartu inclividu?

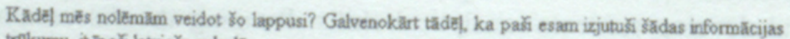
trokkumu, it pach latviełu valoda.

Kas esam mês? Mets esam SF 2. Studiju gada studenti (melsu vărdus Jos varat atrast tabula urkbikiłkinot uz Autori un projekti Ideja radas Pavelacm Simanovičam, Pavels ir arl galvenais idejas

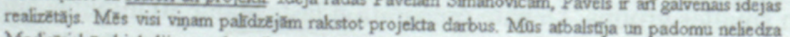
Mediciniskás biologijas un ǵenettikas katedras docetajï - Docente E. Nagle, docente L Zinčenko, profesore A. Rrumina, Dr. Ie. Balode, Dr. L. Leitane


balaloza

The main page of the web link (in Latvian).

Student project works years 2000,2001 
Much of medical genetics is best taught in the context of clinical examples [4]. For this purpose year students passively participate in genetic consultations of the patients with cranio-facial disorders at the Institute of Stomatology. They are subdivided in to smaller groups - only 4-5 students are attending a consultation at the same time. After attending the consultation students are encouraged to express their opinion. Each student assigns his/her evaluation of the consultation. After students have passed genetic pathology they have to prepare a project work to expand their horizons in DOC disorder genetics. It has been increasingly recognized that project- type work can foster independent adult learning and prepare students for life-long and self-directed learning[5].

Students have the opportunity to identify an area of medicine about which they wish to know more [5]. Each year the main topic of the project is given - e.g. in the academic year 2000/2001 the main topic was - "the role of case study in consulting craniofacial disorders". In the academic years 1999/2000, 2000/2001 student projects were published at the web link.

\section{Student assessment}

It is well known that assessment methods should be organized around the primary purpose of improving student learning [6]. Student assessment should be adapted to the curriculum, encourage appropriate learning skills, and reduce emphasis on an uncritical acquisition of facts [7]. The assessment process can also serve as an educational strategy [8].

Students in human biology are assessed during the academic year and in their final examination. Each student has to answer and demonstrate understanding of the subject every week and after each theme there is a colloquy. In the colloquy students have to answer theoretical questions (written test), and in addition solve problems or describe microscopic slides. The pass mark of the colloquy is " 5 ". The final examination takes place during the session. It is known that traditional oral examinations are limited in assessing the broad range of skills and knowledge which students possess [8]. Structured examination can overcome this problem. This examination has three parts:

- multiple choice questions (MCQ);

- theoretical answer;

- demonstration of practical skills.

MCQ gives as maximum as 5 points. 


\begin{tabular}{|cc|}
\hline \multicolumn{2}{|c|}{ Grading } \\
\hline $\begin{array}{c}\text { Number of } \\
\text { correct } \\
\text { answers }\end{array}$ & Points \\
\hline $0-3$ & 0 \\
$4-6$ & 1 \\
$7-10$ & 2 \\
$11-14$ & 3 \\
$15-18$ & 4 \\
$19-20$ & 5 \\
\hline
\end{tabular}

The practical part includes identification of object on microscopic slides. This part of the examination also gives a maximum of 5 points.

\begin{tabular}{|cc|}
\hline \multicolumn{2}{|c|}{ Final grading } \\
\hline Points & Mark \\
\hline Less than 4 & 0 \\
$4-5$ & 1 \\
$6-7$ & 2 \\
$8-9$ & 3 \\
$10-11$ & 4 \\
$12-13$ & 5 \\
$14-15$ & 6 \\
16 & 7 \\
18 & 8 \\
19 & 9 \\
20 & 10 \\
\hline
\end{tabular}

\section{Grading}

Description of the answer

Object is not identified

\section{Points}

Object is identified, student cannot describe the object

Object is identified, incomplete characteristic of the object

Object is identified, correct characteristic of the object 0

Object is identified, correct characteristic of the object, good additional information of the object

Object is identified, correct characteristic of the object, very good additional information about the object

Object is identified, correct characteristic of the object, xcellent additional information about the object

The theoretical answer is evaluated according to the Instruction on studies at $\mathrm{AML} / \mathrm{RSU}$. The theoretical examination includes 3 questions -1 question in cytology, 1 question in genetics, and 1 problem in genetics. The final mark of the examination gives the sum of all parts of the examination. 
If the final mark is lower than " 5 ", the student has to repeat the examination.

All aspects of medical genetics are assessed throughout the semester. During the semester there are 2 colloquys. Each colloquy consists of a theoretical part and a practical part. The practical part includes problem solving, case study or assay writing. There are assessment of knowledge and presentation skills every week by several short factual questions and problem solving. Students are also asked to assess other student's tests. They should ask questions and make comments about the test. Self-assessment of the tests has been introduced to develop critical thinking. After the test is done, students are encouraged to evaluate their own test by of textbooks means and scientific articles. End-of-course assessment (final examination) is carried out on the same day and time for all students. They give written answers (all students have identical questions) to 14 theoretical questions. They also have to solve one problem and to write an optional assay (3-4 topics are offered for the assay). The final examination pass mark is " 5 " (examination papers are evaluated according Instruction on studies at RSU/AML. After the final examination students are invited to discuss and evaluate the results.

After acquiring the study programs in Human Biology and Medical Genetics students should have theoretical knowledge about:

- prokaryotic and eukaryotic cell structure and functions;

- role of ecological factors as causative agents of human diseases;

- interaction between human and other living organisms;

- human ontogenesis, some aspects of human evolution;

- main principles of formal genetics, patterns of inheritance (both Mendelian and non-Mendelian);

- gene expression during ontogenesis;

- the role of genes and environment in the formation of the phenotype;

- heritable enamel and dentin diseases, genetics of oral and craniofacial disorders;

- dental manifestation of the most common genetic pathology;

- genetic counseling in dentistry, prevention of dental genetic pathology.

By the end of these study courses students should be able to show practical skills at:

- karyotyping normal human chromosomes and analysis of abnormal chromosomes;

- gaining familiarity with the ISCN nomenclature for cytogenetic anomalies;

- recording and analysis of family histories (genealogy);

- conducting research in literature

- estimating the risk of genetic disorders (including Bayesian calculation) 


\section{Summary}

This paper gives insight into the biological curriculum taught to students of dentistry at the Latvian Academy of medicine. It shows changes that have happened during a 10-year period in this curriculum. Teaching learning and student assessment methods are described as very important part of he study course. It encourages students to discuss problems, clinical cases, and involve students in the study process. Student project work as a part of the curriculum encourages students for critical thinking and gives skills at the evaluation of scientific literature.

\section{References}

1. Science Curriculum - Biology. http://www.dpi.state.nc.us/curriculum/science/biology.htm

2. Lechner Sybille K. Evaluation of teaching and learning strategies// Medical Education Online [serial online] - 2001. - 6; 4: 1-5

3. Bioethics: debates in human genetics http://www.accessexcellence.com/AE/AEC/AEF/1994/sullivan_bioethics.html

4. Report from the ASHG Information and Education Committee: Medical School Core Curriculum in Genetics. http://www.faseb.org/genetics/ashg/policy/rep-01.htm

5. Murdoch-Eaton Deborah, Jolly Brian. Undergraduate projects-do they have to be within the conventional medical environment? // Medical Education.-2000; 34:95-100

6. Principles and Indicators for Student Assessment System. National Forum on Assessment. http://www. fairtest.org/princind.htm

7. What research says about Student Assessment? http://www.ed.gov/pubs/IASA/newsletters/assess/pt4.html

8. Student Assessment and Testing.

Erika Nagle, Dr.biol., Department of Medical Biology and Genetics, Riga Stradiňš University e-mail: erika.nagle@rsu.lv

Aija Gulbe - Department of Education; head e-mail: sarmite zagere@adm.aml.lv 